\title{
New Insights in Prostate Cancer Development and Tumor Therapy: Modulation of Nuclear Receptors and the Specific Role of Liver X Receptors
}

\author{
Laura Bousset ${ }^{1,2,+}$, Amandine Rambur ${ }^{1,2,+}$, Allan Fouache ${ }^{1,2,+}$, Julio Bunay 1,2 (DD, \\ Laurent Morel ${ }^{1,2}$, Jean-Marc A. Lobaccaro ${ }^{1,2, * \mathbb{D}}$, Silvère Baron ${ }^{1,2, *}$, Amalia Trousson ${ }^{1,2, \ddagger}$ \\ and Cyrille de Joussineau ${ }^{1,2, \ddagger}$ \\ 1 Université Clermont Auvergne, GReD, CNRS UMR 6293, INSERM U1103, 28, place Henri Dunant, \\ BP38, F63001 Clermont-Ferrand, France; laura.bousset@uca.fr (L.B.); amandine.rambur@uca.fr (A.R.); \\ allanfouache76@gmail.com (A.F.); julio.bunay_noboa@uca.fr (J.B.); laurent.morel@uca.fr (L.M.); \\ amalia.trousson@uca.fr (A.T.); cyrille.de_joussineau@uca.fr (C.d.J.) \\ 2 Centre de Recherche en Nutrition Humaine d'Auvergne, 58 Boulevard Montalembert, \\ F-63009 Clermont-Ferrand, France \\ * Correspondence: j-marc.lobaccaro@uca.fr (J.-M.A.L.); silvere.baron@uca.fr (S.B.); \\ Tel.: +33-473-407-416 (J.-M.A.L.); +33-473-407-412 (S.B.); \\ Fax: +33-473-407-042 (J.-M.A.L.); +33-473-178-387 (S.B.) \\ + These authors contributed equally to this work. \\ $\ddagger$ These authors contributed equally to this work.
}

Received: 29 June 2018; Accepted: 9 August 2018; Published: 28 August 2018

\begin{abstract}
Prostate cancer (PCa) incidence has been dramatically increasing these last years in westernized countries. Though localized PCa is usually treated by radical prostatectomy, androgen deprivation therapy is preferred in locally advanced disease in combination with chemotherapy. Unfortunately, PCa goes into a castration-resistant state in the vast majority of the cases, leading to questions about the molecular mechanisms involving the steroids and their respective nuclear receptors in this relapse. Interestingly, liver $X$ receptors (LXR $\alpha / N R 1 H 3$ and LXR $\beta / N R 1 H 2)$ have emerged as new actors in prostate physiology, beyond their historical roles of cholesterol sensors. More importantly LXRs have been proposed to be good pharmacological targets in PCa. This rational has been based on numerous experiments performed in PCa cell lines and genetic animal models pointing out that using selective liver $X$ receptor modulators (SLiMs) could actually be a good complementary therapy in patients with a castration resistant PCa. Hence, this review is focused on the interaction among the androgen receptors (AR/NR3C4), estrogen receptors (ER $\alpha / N R 3 A 1$ and $\mathrm{ER} \beta / \mathrm{NR} 3 \mathrm{~A} 2$ ), and LXRs in prostate homeostasis and their putative pharmacological modulations in parallel to the patients' support.
\end{abstract}

Keywords: prostate cancer; metastasis; LXRs; androgens; estrogens; cholesterol; oxysterols; signaling pathway

\section{Introduction}

Prostate cancer (PCa) rarely appears before the age of 40 years and is diagnosed in men of approximately 70 years old. Already known risk factors include age, family history, ethnicity, and internal steroid hormones levels, whilst there are also emerging carcinogenic factors, including diet, lifestyle, and exposure to xenobiotics. PCa requires androgens for growth, and androgen deprivation has, for decades, been the principal strategy to treating advanced disease. The increased incidence of PCa in many countries has been partly attributed to changes in diagnostic methods. Despite its 
controversy, introduction of the prostate-specific antigen (PSA) assay as a screening method during the last decade has led to an increase in incidence. However, this alone does not explain the observed continuing rise. Besides, epidemiological studies have also pointed out that environmental factors could influence PCa risks, even though they are difficult to define [1]. PCa is the paradigm of the endocrine-related tumors, together with breast cancer. Various hormones, mainly steroids and their respective nuclear receptors (NRs), have a prominent role in the development of PCa. Hence, unusual levels of testosterone and dihydrotestosterone (DHT) in prostate tissue are suspected to increase the risk of developing cancer [2], and estrogens are believed to have an important role as well [3,4].

NRs are part of a superfamily encompassing 48 members within humans. As DNA-binding proteins, they can control the transcription of genes whose products are fundamental for important physiological functions (for a review see Evans and Mangelsdorf [5]). Schematically, NRs are composed of three major independent functioning domains (Figure 1): a N-terminal involved in the regulation of the non-ligand dependent transcriptional activity, a central DNA-binding domain, and a C-terminal ligand-binding domain carrying a potential ligand-binding pocket controlling the ligand-dependent transcriptional activation function [6].

The steroid receptors are within the cytoplasm in the absence of a ligand and are bound to heat shock proteins that impede the shuttling to the nucleus (Figure 1).

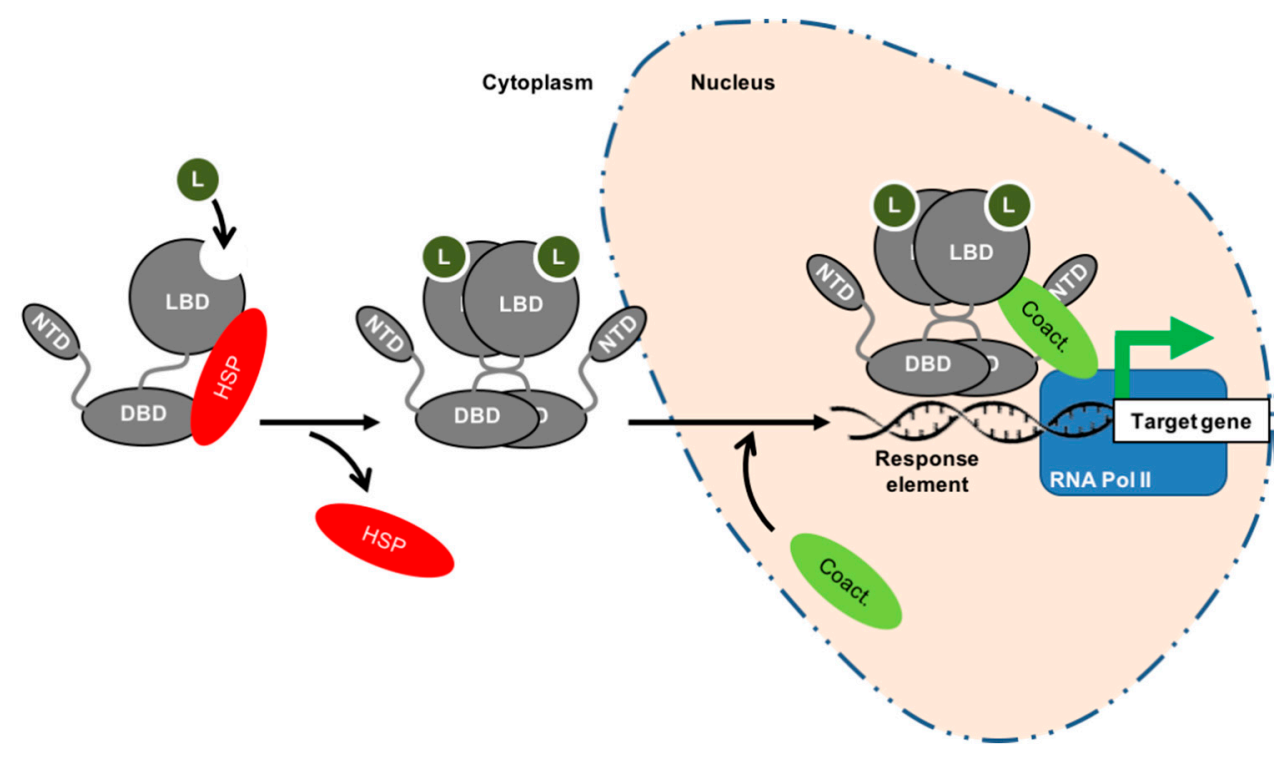

Figure 1. Schematic structure and functioning of steroid receptors. Nuclear receptors are composed of an N-terminal domain (NTD), a DNA-binding domain (DBD) responsible of the binding to the DNA-target sequences usually located within the promoters of the targets genes and a C-terminal ligand-binding domain (LBD), which is specific to the molecule. Canonically, it is admitted that steroid receptors are located within the cytoplasm in the absence of hormone, bound to heat shock proteins (HSP) that impede shuttling to the nucleus. The binding of the steroid (L) allows the chaperones to unbind from the receptor and migrate to the nucleus after a homodimerization. The binding of co-activators (Coact.) makes the recruitment of the transcriptional machinery possible, along with the RNA polymerase II (RNA Pol II), the transcription of the target gene, and the physiological effects.

However, other types of NR, such as the liver $X$ receptors (LXR $\alpha / N R 1 H 3$ and LXR $\beta / N R 1 H$ ), function in a heterodimer with retinoid $X$ receptors (RXRs, the receptor for 9-cis retinoic acid, NR2B1-3). In such signaling systems, the heterodimer complex resides bound to DNA in the absence of a ligand, with transcription blocked by the presence of co-repressors (Figure 2). 


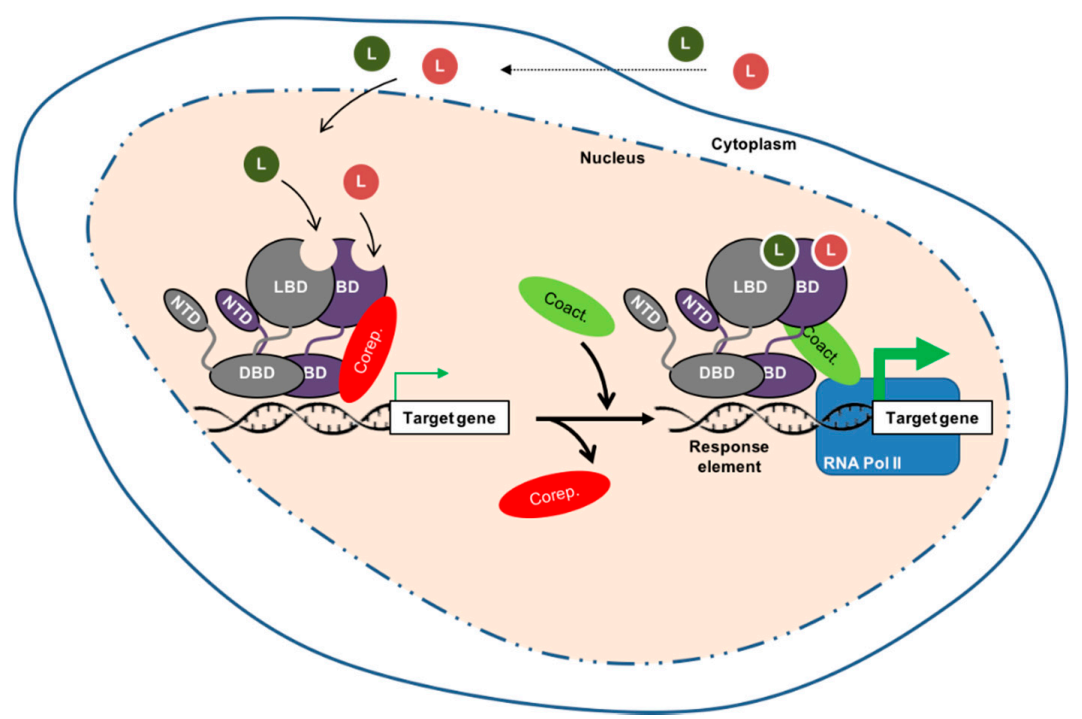

Figure 2. Schematic structure and functioning of nuclear receptors bound as heterodimers with retinoid X receptors (RXR). The non-steroid nuclear receptor (grey) is supposed to be bound with RXRs, a receptor for 9-cis retinoic acid (deep purple), to the DNA. In absence of ligand, the transcriptional activity is blocked (thin green arrow) by co-repressors (Corep.). As for the steroid receptors, the binding of co-activators (Coact.) makes possible the recruitment of the transcriptional machinery, along with the RNA polymerase II (RNA Pol II), the transcription of the target gene (thick green arrow), and the physiological effects.

Ligand binding triggers major conformational changes in the receptor's ligand-binding domain which leads to the dissociation of chaperones and/or corepressors, nuclear translocation (when necessary) and DNA-binding, and the recruitment of coactivators. Thus, it initiates gene transcription [7] (Figures 1 and 2). Hence, in the presence of an agonist in the ligand-binding pocket, corepressors dissociate and the recruitment of transcriptional coactivators is favored. Reciprocally, interactions with an antagonist represses association with coactivators and enables corepressor recruitment. The ligand-binding domain may also contribute to the modulation of the N-terminal AF-1 through inter-domain crosstalk, allowing activating domains to recruit coactivators individually or in a synergistic manner [7].

\section{Nuclear Receptors Are Fundamental for Prostate Physiology}

Androgen [8] and/or estrogen [9] deregulations have been associated with the development of PCa. Their respective NRs are targeted in the treatment of this tumor. Besides these classical steroid NRs, newly considered steroid receptors such as LXR $\alpha$ and LXR $\beta$ [10] have emerged as interesting players in both prostate homeostasis and carcinogenesis [11-13]. This section will be focused on the androgen (AR/NR3C4), estrogen (ER $\alpha / N R 3 A 1$ and ER $\beta / N R 3 A 2)$, and oxysterol (LXRs) receptors, and their putative interactions in maintaining prostate physiology.

\subsection{Role of AR in Prostate Physiology and in PCa}

Since pioneering work from Higgins and Hodges was published in 1941 [8], it has been well established that androgen regulation signaling is one of the hallmarks of PCa. If testosterone is the principle circulating androgen, the most active androgen in the prostate remains $5 \alpha$-dihydrotestosterone (DHT), produced by conversion of testosterone by $5 \alpha$-reductase type 2 (SRD5A2), which binds their nuclear receptor with two to ten-fold higher affinity than testosterone [14]. DHT exerts its activity through AR-regulated transcription of genes involved in cell differentiation, development, survival, and function of the prostate in adulthood. Androgens may 
also exert rapid, AR-dependent non-genomic effects. In this process, cytoplasmic AR can induce kinase-signaling pathways such as mitogen-activated protein kinases (MAPK) or phosphoinositide 3-kinase (PI3K) / AKT, which ultimately influence AR signaling through the phosphorylation of AR itself or AR co-regulators (for a review see [15]). Part of this mechanism could explain therapeutic failures when anti-androgens have no effect on androgen target genes despite AR remaining active.

\subsubsection{Androgens Are Involved in Prostate Differentiation, Growth, and Functioning}

Various knock-out models for AR have pointed out that the initiation of prostate development needs a functional AR [16], even though a correct organization of the future prostate also involves mesenchymal/epithelial interactions, in which AR is required at the stromal level. Cunha and colleagues [17] showed that AR signaling is needed in the mesenchymal compartment for initiation of prostate development, but not in the epithelial compartment. The stromal cells express AR and secrete peptide growth factors in response to androgen signaling [18,19], which contribute to the prostate differentiation. Binding of these growth factors to their respective receptors on basal cells promotes their proliferation and differentiation first into intermediate cells, then into fully differentiated luminal cells [20]. Conversely, basal cells do not have AR [21,22]. In adulthood, maintenance of the prostate gland depends on the balance of growth-survival/apoptosis driven by androgens, which promote the survival of luminal epithelial cells. In animal models, supra-physiological levels of androgens result in an increase in cellular proliferation in the prostate [23]. Conversely, castration induces apoptosis in about $70 \%$ of luminal epithelial cells in adult male rats but has little or no effect on basal and stromal cells [24].

\subsubsection{Androgens Drive Proliferation of Luminal Epithelial Cells in PCa}

The malignant switch from benign luminal cells to cancerous adenocarcinoma cells is poorly understood, but regardless, AR activity still drives proliferation. This applies both in tumors which are dependent on circulating androgens and in more advanced, castrate resistant disease [25-27]. This signaling pathway pathologically allows androgen/AR complexes to bind to and enhance expression of survival and proliferation genes that are normally not regulated by these complexes in either intermediate cells or luminal cells [25-27]. Using ChIP-on-Chip and ChIP-Seq experiments, research groups have reported thousands of AR direct binding events in PCa cell lines and tissues, furthermore showing different binding patterns depending on the stages of cancer [28-30].

\subsection{Role of ER in Prostate Physiology and in PCa}

The physiological functions of estrogens in the prostate, other than their activity as antiandrogens, have been unclear for many years. The development of genetic mouse models and their study have helped decipher the role of $17 \beta$-estradiol and its receptors in the prostate. $17 \beta$-estradiol activity is mainly mediated through its specific nuclear receptors, ER $\alpha$ (NR3A1) and ER $\beta$ (NR3A2) (for a review see Yaşar et al. [31]). As with AR, ERs control transcription via binding to distinct DNA sequences at target genes or through their non-genomic activity. In non-malignant human adult prostate tissue, ER $\alpha$ is mainly expressed in the stromal compartment where it is involved in stromal cell proliferation and differentiation [32], and it can be found in less than $2 \%$ of epithelial cells where it drives estrogen-mediation epithelial cell proliferation [33,34]. Conversely ER $\beta$ is detected in $90 \%$ of epithelial cells [35-37], where it promotes cell homeostasis and differentiation [38].

During PCa initiation and progression, stromal ER $\alpha$ expression remains but up to $80 \%$ of all epithelial cells show an expression of ER $\alpha$ that rises from 0-2 to 80\% in PCa [37]. Inversely, epithelial cells lose ER $\beta$, as it drops from 90 to $15 \%$ of cells in PCa $[35,39,40]$. Finally, the TRAMP and PB-Cre4/Pten loxP PCa mouse models have helped to understand the respective opposite roles of both ERs, along with the significance of this change that is seen in PCa. While epithelial ER $\alpha$ is thought to be responsible of estrogen-mediated PCa growth, epithelial ER $\beta$ is believed to have protective roles [41].

Epidemiological data have shown controversial results regarding the role of circulating estrogens. Local steroid production by prostate tumors, rather than circulating steroids, may play a major role in 
driving PCa growth in men following androgen deprivation therapy [42]. While current research on the role of intracrine steroids focuses on intratumoral androgens, it is important to note that aromatase (CYP19A1), which catalyzes estradiol production from testosterone, is also altered in PCa tissues [43] and CYP19A1 expression could be 30-fold higher than normal in PCa metastatic tissues [44].

\subsection{LXRs as Emerging Factors Regulating Prostate Physiology}

LXR $\alpha$ and LXR $\beta$, encoded by two distinct genes, are composed of 447 and 460 amino acids, respectively (for a review see $[10,45]$ ). They cannot be formally considered as true isoforms; however, they share $77 \%$ of their identity within their DNA- and ligand-binding domains. Initially described as orphan receptors, Mangelsdorf's group demonstrated more than 20 years ago that LXRs were actually the receptors for oxysterols, oxidized derivatives of cholesterol [46,47]. Because oxysterols were described as bona fide ligands, it was suspected that LXRs could be involved in the regulation of cholesterol metabolism. Indeed, this was further demonstrated by the phenotype analysis of LXR-deficient mice [48]. Hence, the activation of both LXRs by their cognate oxysterol ligands reduces the intracellular concentration of cholesterol. This occurs through several means: (1) the increase of the cholesterol efflux via the transcription of $A B C G 1$ and $A B C A 1$, two membrane transporters and target of LXRs; (2) the inhibition of the cholesterol influx by increasing the ubiquitin ligase inducible degrader of the LDL receptor (IDOL), which targets the LDL receptor; (3) the increase of cholesterol metabolism into bile acids (induction of CYP7A1) or steroids (induction of StAR); and (4) the increase of cholesterol storage.

In the prostate, we and others have explored the physiologic role of LXRs. Both isoforms are expressed in the prostate, in epithelial as well as in stromal cells. However, so far, it has not been possible to dissociate the exact role of each LXR isoform as they both compensate each other [49]. Fukuchi et al. first pointed out that ABCA1 was downregulated by AR in LNCaP cells [50]. Furthermore, the same group showed that the activation of LXRs by the synthetic agonist T0901317 slows down LNCaP proliferation [51], suggesting a role of LXRs in the progression of CaP, or at least showing that these receptors could be pharmacologically targeted. LXRs and some of their target genes were found to be less accumulated during the progression of the androgen-dependent into androgen-independent relapsed tumors in a xenograft model [52].

The role of LXRs in the control of the apoptosis of prostate cells was also shown using various natural or synthetic ligands [11]; this occurs through the modulation of the membrane cholesterol content associated with the lipid rafts, thus decreasing the PI3K and survival pathways. Using new cellular models derived from the dorsal prostate, we showed that LXRs control both protein kinase B (or AKT) and MAPK phosphorylation pathways in a normal prostate's cell cycle [12]. This point is of importance as the Ras/MAPK pathway is essential to maintaining cellular homeostasis because of its implication in cell proliferation and differentiation. Additionally, this pathway is the second major signaling pathway whose deregulation has been associated to prostate tumorigenesis: it has been found up-regulated in $43 \%$ of primary tumors and in the greatest majority of metastases [53]. Furthermore, the suppressor of cytokine signaling 3 (SOCS3), which is able to inhibit p42/p44 MAPK signaling [54] and the proliferation and migratory ability of cancer cells, is upregulated upon LXR activation $[55,56]$. Janus kinase/signal transducers and activators of transcription (JAK/STAT) and Wingless/Integrated (Wnt) pathways could also be deregulated in PCa [53]. Interestingly, LXR activation represses the JAK/STAT signaling pathway in the liver and decreases $\beta$-catenin accumulation, a crucial mediator of the Wnt pathway [57].

In parallel, our group pointed out that LXR-deficient mice fed with a high cholesterol diet presented a neoplasia within the prostate epithelium, characterized by the downregulation of the tumor suppressor Homeobox protein NKX3.1 and beta-microseminoprotein MSMB and the upregulation of pro-oncogenic factors such as CyclinD1 and CyclinD2 [58]. This was definitively due to the accumulation of the oncogene and histone methyl transferase enhancer of Zeste Homolog 2 (EZH2), whose overexpression has been described in patients with an aggressive PCa [59]. The question 
regarding any expression change with cancer progression is unclear. Indeed, Oncomine ${ }^{\circledR}$ analysis did not show any difference for $\operatorname{LXR} \alpha$, while a slight significant difference was observed for $\mathrm{LXR} \beta$ [58].

Altogether, ex vivo and in vivo studies suggest that LXRs could be implicated in the progression of PCa and, thus, could represent a pharmacological target for its treatment (Figure 3).

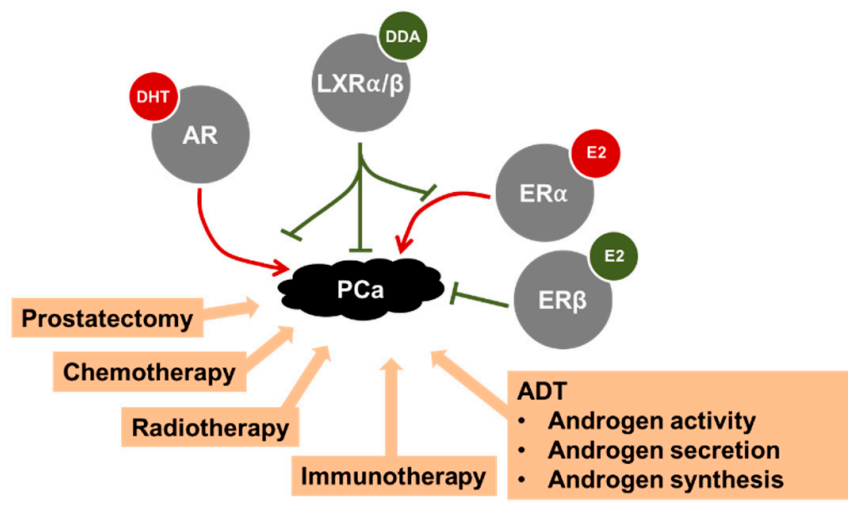

Figure 3. Summary of the various treatments proposed to treat PCa. A focus is made on some nuclear receptors. The androgen (AR) and estrogen receptor (ER) $\alpha$ have deleterious effects on prostate cancer (PCa) progression when activated by their respective ligands dihydrotestosterone (DHT) and $17 \beta$-estradiol (E2). Conversely, nuclear oxysterol receptors $(\mathrm{LXR} \alpha / \beta)$ and ER $\beta$ block the progression of PCa in animal models when activated by their respective ligands. As indicated, AR and ER $\alpha$ activity in PCa could be modulated by LXRs, directly or indirectly. For more details see the text. DDA: dendrogenin A.

\subsection{Androgens, Estrogens, and Oxysterols Interact in the Prostate}

Despite their specific respective physiological roles on prostate physiology (see above sections), androgens, estrogens, and oxysterols cross interact through the transcriptional activation of their respective NRs.

\subsubsection{LXRs Regulate the Availability of Active Steroids}

As described above, prostate homeostasis is sensitive to steroids such as androgens and estrogens. All of these molecules derive from cholesterol. Regarding the binding to their respective receptors, the availability of androgens [60] and estrogens can be modulated by sulfotransferases, which inactivate the steroid activity [61]. Previous work has reported that sulfotransferase family 2A member 1 (SULT2A1) deactivating androgens is a LXR-target gene [62]. Indeed, ligand activated LXRs deprive cells from androgens through the increase of SULT2A1. Conversely, LXRs inhibit the expression of steroid sulfatase STS, an enzyme involved in the activation of androgens in prostate [63]. The level of active estrogens is also dependent of the levels of the estrogen sulfotransferase EST/SULT1E1. As for androgens, sulfated estrogens cannot bind to and activate ER activities [64].

\subsubsection{AR, ER, and LXR Interaction within the Prostate}

PC-3 AR-negative cells display a higher accumulation of LXR target genes [65], such as $A B C A 1$ and $A B C G 1[13,50,52]$. A similar accumulation is also seen mouse models and in patients receiving androgen deprivation therapy [66]. Benign prostatic hyperplasia is a pathological situation due to an excessive activity of AR and the production of DHT [67]. Using transgenic animals, we [49] and others [68] described LXR $\alpha$ as a key modulator of the cross talk between the stromal and epithelial compartments, which is essential for the integration of androgen signaling in the prostate and its effect on the epithelium. We pointed out that $\operatorname{LXR} \alpha$-deficient mice have increased secretory activity in the epithelium resulting from a deregulation of the androgen signaling. No clear specific role 
was identified for LXRs between the epithelial and the stromal compartments, suggesting a complex paracrine network regulated by these receptors [49]. Likewise, Tsui et al. [69] pointed out that LXR expression was higher in androgen-sensitive LNCaP cells than in other PCa cell lines, and activating LXRs by T0901317 in LNCaP cells decreases their AR accumulation and PSA production. Overall, AR and LXRs are definitively interconnected. Even it is not fully demonstrated for the prostate, it has also been shown that ERs down-regulate $L X R \alpha$ mRNA in mouse macrophages [70,71], through an estrogen response element in the $L X R \alpha$ promoter [70], suggesting a putative interaction between these two classes of receptors.

\subsection{NR Activity Can Be Altered in Prostate Physiology by Environmental Disrupting Chemicals}

Cholesterol-derived molecules are not the only ones that are able to modulate AR, ER, and LXR transcriptional activity (Figure 3). Indeed, environmental disrupting chemicals (EDCs) (reviewed in Delfosse et al. [72]) affect physiology in various ways by mimicking natural endogenous molecule activity, antagonizing their action, or modifying the synthesis, metabolism, and transport of these endogenous compounds. Due to their estrogen-like structure, the main harmful effects of EDCs have been attributed to their interference with hormone signaling mediated by NRs [72]. Hence, the physiologic roles controlled by the targeted NRs are altered. Historically, studies were focused on ER $\alpha$ and ER $\beta, A R$, and thyroid receptors TR $\alpha$ (NR1A1) and TR $\beta$ (NR1A2). Then, because disorders of metabolic pathways have been associated to a higher risk of developing PCa, NRs controlling these processes have been the center of interest. Among them, peroxisome proliferator activated receptors (PPAR $\gamma /$ NR1C3), rexinoid receptors (RXRs/NR2B1-3), and LXR $\alpha$ and $\beta / N R 1 H 3$ and 2 are abundantly studied due to their potential to be pharmacologically targeted (for a review on LXRs please refer to Maqdasy et al. [10]).

\section{Lipid Metabolism, Angiogenesis and Immunity Are Altered in PCa}

As for other cancers, prostate tumorigenesis is a multifactorial process that depends on cell modifications to allow for proliferation and growth. For that purpose, tumor cells usually (1) adapt their metabolism to produce enough cell components [73] and (2) induce molecular modifications to escape from cell cycle control.

\subsection{Lipid and Cholesterol Metabolism in Cancer Cells}

Among the numerous metabolic alterations that fuel cells and allow for the increased rate of growth and proliferation in cancer cells, the Warburg effect is a metabolic switch where cancer cells reprogram their glucose metabolism for "aerobic glycolysis", a process usually favored in anaerobic conditions [74]. Another example of an adaptation is citrate and fatty acid production. While citrate, necessary for secretion in prostatic fluid, is produced in large amount, it is used as a substrate for de novo fatty acid synthesis [75], which is found to be increased in PCa development [76].

A deregulation in cholesterol homeostasis has also long been associated to PCa [77,78]. Indeed, White described an "accumulation of crystals of lipid nature in tumors" suggesting that "cholesterol might be associated in some way with the regulation of cell proliferation" [78]. Interestingly this suspicion was later confirmed by Swyer who identified a two-fold increase of cholesterol content when prostates were affected by a hypertrophy [77]. More recently and using imaging data, prostate cancer aggressiveness has been associated with an aberrant accumulation of esterified cholesterol in lipid droplets [79]. However, no clear link has been made between cholesterolemia and Gleason score, positive nodal status, and /or positive surgical margins [80]. Hydroxy-3-methylglutaryl-coenzyme A reductase (HMGCR) is the key enzyme in endogenous de novo cholesterol synthesis and is inhibited by statins. Interestingly, the use of statin by patients suffering a hypercholesterolemia has been associated with improved PCa specific survival, particularly in men undergoing radiotherapy [81].

Additionally, and as presented above, LXRs increase the apoptosis of PCa cell lines by modifying the membrane distribution of cholesterol. Indeed, we pointed out that activated LXRs by various 
natural or synthetic ligands could induce smaller and thinner lipid rafts and downregulate AKT phosphorylation in these lipid rafts [13]. LXRs also regulate the first step of prostate carcinogenesis since, as previously presented, LXR-deficient mice fed a high cholesterol diet have prostatic intra-epithelial neoplasia while wild-type mice do not. This indicates that LXRs could act as gatekeepers against PCa when cholesterol homeostasis tends to be destabilized.

Conversely, AR and androgens have been implicated in the increase of the intracellular concentration of cholesterol in PCa cells by inducing the accumulation of HMGCoA and transcription factor sterol response element binding protein (SREBP2), which increases cholesterol de novo synthesis, and by decreasing the amount of ABCA1 [82]. AR also decreases LXR activation in PCa by competing for their coactivators. For a review regarding the interaction between AR and LXRs refer to Cariello et al. [83].

Besides an increased endogenous synthesis of lipids, environmental factors such as food intake play a critical role in cancer development. Hence, it has been considered that food intake could represent the principal source of cholesterol [84]. It is thus not surprising that an enriched lipid diet could be described as a risk factor for developing PCa [85]. A similar positive association with a higher risk of developing PCa has been found for the consumption of products of animal origin [86].

\subsection{Modification of Angiogenesis and Immunity}

Immune system dysregulation is another feature of cancer development. Some studies show an interesting correlation between recurrent prostatitis and PCa, suggesting the importance of the immune system in prostate carcinogenesis [87]. Indeed, systemic and in situ inflammation could be observed in the tumor and stromal microenvironment. This inflammation is suspected to contribute to the tumor development by the supply of bioactive molecules, such as growth factors produced by the microenvironment immune cells. PCa has also been associated with the accumulation of inducible nitric oxide synthase (iNOS) [88]. Cyclooxygenase (COX) 2, a pro-inflammatory enzyme synthetizing iNOS is highly expressed in tumor-associated macrophages [89]. In the same way, IL6 is highly expressed in PCa and promotes tumor growth at least in part via PI3K/AKT signaling activation $[90,91]$. Noteworthy, LXRs downregulate inflammation by the parallel inhibition of iNOS, COX2, and IL6 expression [92,93]. Moreover, LXR activation is able to stimulate an antitumor immune response by promoting the secretion of IFN $\gamma$ by macrophages and T-cells, a phenomenon that has been associated with an increase in survival of mice injected with lung carcinoma cells [94].

Tumor expansion depends on the availability of nutrients and oxygen and the ability to eliminate the waste produced by the high metabolism of the tumor cells. To avoid the microenvironment becoming hypoxic and poor in nutrients, cancer cells favor angiogenesis by increasing the production of vascular endothelial growth factor (VEGF). In PCa cells, VEGF is highly expressed. Moreover it has been shown that LXRs are able to decrease VEGF signaling by modifying the distribution of cholesterol at the membrane $[95,96]$. Logically, synthetic LXR agonist T0901317 blocks migration of endothelial cells and vessel tube formation [97].

Altogether, modulation of cholesterol homeostasis has a strong effect both on inflammation and angiogenesis within the prostate, two steps that are important for the progression of PCa to an advanced form of disease. Hence, the fact that identified metabolisms are altered during tumor development and metastasis process allows for the future possibility of using inhibitors of lipid synthesis, inflammation, and/or angiogenesis in patients with PCa.

\section{Management of Prostate Cancer and Treatments}

Even though this review is focused on the NRs in PCa, it is important to have a clear overview of the various management strategies as, according to what was described in the previous sections, anti-steroid therapy or novel molecules targeting LXRs could be applied depending on the stage of PC. Hence, medical care of the patients is based on whether the tumor is localized, if it is advanced, metastasized, or resistant to castration. Apart from classical treatments such as radio- or chemotherapy, specific strategies have been developed to target steroid production and have shown some efficacy. 
Still, new strategies are to be developed to increase treatment efficacy. The treatments could also be combined in order to increase their efficacy.

\subsection{Local PCa}

Less than $5-10 \%$ of patients with low-grade, low-volume tumors will develop a PCa in the 10 years following diagnosis [98]. Based on the usually late age of diagnosis (usually above 70 years of age), deferred treatment and active surveillance are proposed to patients in order to prevent over-treatment that reduces mortality while decreasing the quality of life. About $80 \%$ of men with PCa have a localized disease [99]. For localized or locally advanced disease, the choice of treatment will be depending on the risk of progression of the tumor, life expectancy, and patient wishes. According to the European Association of Urology guidelines, radical prostatectomy is usually proposed to patients with low to high-risk PCa since they have a life expectancy $>10$ years. Radiation therapy is a suitable option for low-risk PCa and should be used in combination with androgen deprivation therapy (ADT) for intermediate/high-risk localized and locally advanced PCa.

\subsection{Advanced and Metastatic $P C a$}

Median survival for a patient newly diagnosed with metastatic PCa (about 5\%) is at least 42 months. However, this is largely heterogeneous [100], and the first line standard approach for patient with advanced PCa is ADT [101]. Three main pharmacological treatments are proposed to block androgen effects. The first is treatment with LHRH ligands [102]. On one hand, agonists (mainly goserelin leuproline, and triptorelin) are able to downregulate the LHRH receptor, resulting in a huge decrease of LH/FSH secretions and testosterone production. On the other hand, LHRH antagonists (abarelix and degarelix) directly block the LHRL receptor and also result in the shut-down of testosterone production. The second treatment is the blockade of androgen synthesis. CYP17, the limiting enzyme for the production of androgens, is upregulated in CRPC [44] and can be inhibited by abiraterone treatment [103]. Ketoconazole has also been shown to block the adrenal steroidogenesis. This metabolic pathway is important as HSD3B1, which converts DHEA to androstenedione in prostate tissue as well as in the adrenal gland, is sometimes found highly expressed in PCa [104]. Likewise, AKR1C3, which converts weak adrenal androgens (e.g., DHEA and androstenedione) into $\mathrm{T}$ and DHT, is a good pharmacological target [105]. The third treatment is antiandrogens to antagonize AR and androgen action. These compounds could have either a steroid structure as cyproterone acetate or a non-steroid backbone, such as bicalutamide, flutamide, or nilutamide. Enzalutamide, also a non-steroidal antiandrogen, prevents AR nuclear translocation and has a higher affinity for AR than the widely used bicalutamide [106].

Together with ADT, chemotherapy may be performed. Recent clinical trials and meta-analyses show a $9 \%$ improved benefit on overall survival at four years of using docetaxel chemotherapy in combination with ADT for metastatic hormone-sensitive PCa [100].

\subsection{Castration Resistant Prostate Cancer}

Most patients experience tumor growth recovery despite being on ADT within a median of 18 to 24 months [107] and progress to a lethal stage called castration-resistant PCa (CRPC). The emergence of this aggressive form of PCa is diagnosed when blood PSA increases despite a low serum testosterone, followed by a progression of the disease with the appearance of new symptoms and bone or soft tissue lesions [108]. About 33\% of men with a rise of PSA level will develop bone metastasis within two years [109], even though patients with CRPC are highly heterogeneous. Various genetic alterations have been associated to this CRPC, such as alterations in PI3K or in Wnt pathways and in the cell cycle or DNA repair processes [110].

However, AR pathway harbors the main alterations. Five general mechanisms are usually described to explain the emergence of CRPC. The first is the overexpression of the protein AR [111,112], even though AR expression is lost in a subset of metastatic CRPC (mCRPC) [113] and the mechanisms 
associated to this complete androgen independence remain unclear. The second are the mutations of AR [114], which could induce a hypersensitivity to low levels of androgens, an antagonist-to-agonist switch for antiandrogens, or a receptor able to respond to non-canonical agonists like non-androgen steroids. The third is the upregulation of AR coactivators such as ARA70, which plays an important role in the antiandrogen antagonist-to-agonist switch in the DU145 PCa cell line [115], the forkhead box protein (FOXA1) [116], immunoglobulin transcription factor (ITF2), steroid receptor coactivator (SRC1) [117], lysine methyltransferase (EZH2) [118], and aldo-keto-reductase (AKR1C3) [119]. Conversely to breast cancer, no downregulation of co-repressors has been reported so far. The fourth is the activation of AR by tyrosine-kinase receptors linking the androgen regulated pathway with the growth factor signaling pathways. Hence, insulin like growth factor (IGF-1), keratin growth factor (KGF), and epidermal growth factor (EGF) can activate AR in vitro in the absence of a ligand [120]. Likewise, receptor tyrosine-protein kinase erbB-2 (Her-2/neu) overexpression has been observed in $67 \%$ of CRPC tissue versus $20 \%$ of hormone-naive tissue [121,122] and participates in the activation of AR in absence of androgen through MAPK signaling [123]. Her-2/neu activation also increases AR stability [124]. The firth is the intratumoral synthesis of active androgens. The primary source of androgens for the tumor cells are the testes, even though the adrenal glands [125] could, to a less extent, provide inactive androgens that are transformed into active hormones (5-10\%). Additionally, as described above, some tumors synthesize their own active androgens by the abnormal production of cytochrome CYP17A1 and AKR1C3 or a higher activity of SRD5A1/3, which allows for the conversion of testosterone into DHT [126].

\subsection{New Therapeutic Strategies for PCa Beside Steroids and NRs}

For few years, therapeutic strategies have attempted to reduce overtreatment of metastatic CRPC (mCRPC) patients, which only offers little benefits to life expectancy while having a negative effect on quality of life. One strategy to prevent over-diagnosis of PCa has been to limit systematic PSA screening. However, metastatic PCa has been increasing in the USA. As PCa mortality is due to the progression of the disease, the new challenge for physicians and researchers is to propose new options to treat advanced and metastatic forms of PCa.

Chemotherapy with cabazitaxel, a novel taxane-derivate drug, is now a second-line option for docetaxel-resistant cancer. A TROPIC phase III clinical trial demonstrated an overall survival benefit of cabazitaxel (15.1 months) versus mitoxantrone (12.7 months) in docetaxel-resistant CRPC [127].

As PCa preferentially metastasizes in bone $(90 \%)$ and primarily forms osteoblastic lesions [128], these metastases are incurable and contribute to tumor-specific morbidity and mortality [129]. Hence, radium 223, which is a radiopharmaceutical molecule, similar to calcium, improves overall survival by binding to newly formed bone and emitting radiation to induce apoptosis in the surrounding tumor cells [130]. Bisphosphonates slow down bone resorption and prevent loss of bone mass by binding hydroxyapatite and inhibiting osteoclast activity. Among them, zoledronic acid shows a delays in the emergence of skeletal-related events by $36 \%$ [131]. Targeting the bone microenvironment can also reduce skeletal-related events. Denosumab is a monoclonal antibody, which binds to receptor activator of nuclear factor kappa-B (RANK) ligand, interfering with the activation of RANK at the surface of osteoclasts and thus inhibiting their proliferation, function, and survival while decreasing bone resorption. This molecule delays the time of apparition of first bone metastasis for about four months [132].

Cancer therapy is now facing the new era of immunotherapy. Recently, focus was made on immunotherapy of PCa since sipuleucel-T demonstrated significant, even limited, benefit on overall survival in a clinical trial on asymptomatic or little symptomatic mCRPC patients [133].

Even in CRPC, AR remains active and PCa cells are sensitive to a second-line of ADT. For CRPC patients, specific drugs have been developed such as abiraterone acetate and enzalutamide (see above).

Unfortunately, initial responders to second generation ADT inevitably become resistant to enzalutamide and abiraterone, and others develop acquired resistance [134]. So, for the last few 
years, research has been focused on the comprehension of the molecular mechanisms inducing these resistances [134].

The discovery of new mechanisms of resistance will allow for the deciphering of new molecular pathways and encourage the development of future molecules, such as the currently under trial apalutamide (ARN-509, Janssen, Horsham, PA, USA), darolutamide (ODM-201, Orion, Espoo, Finland), proxalutamide (GT0918, Suzhou Kintor Pharmaceuticals, Suzhou, China), seviteronel (Viamet Pharmaceuticals, Research Triangle Park, NC/Innocrin Pharmaceuticals, Durham, NC, USA), ASN001 (Asana Biosciences, Lawrenceville, NJ, USA), and TRC253 (Janssen).

Recent results suggest that oxysterols and LXRs have a protective role against progression and dissemination of tumor cells. Indeed 27-hydroxycholesterol, a LXR ligand, reduces the invasive potential of LNCaP and PC3 PCa cells in in vitro cell invasion assays [135]. Pencheva and colleagues demonstrated in a melanoma model that treatment with an LXR agonist affected secretion of APOE by stromal cells resulted in a decrease in tumor growth, neoangiogenesis, and metastatic dissemination [136]. Likewise, Segala et al. pointed out that dendrogenin A, a newly discovered cholesterol metabolite and activator of LXRs, is able to specifically induce lethal autophagy of cancer cells in vitro and in vivo [137].

\section{Conclusions}

As already presented, cholesterol is an important molecule whose concentration needs to be controlled in prostate physiology. Since cholesterol is associated with the aggressiveness of prostate adenocarcinoma, targeting its metabolism appears to be an interesting theoretical therapy. Two pathways can be targeted: the mevalonate pathway, which is inhibited by the statins, and the LXR signaling pathway, which could be activated to tighten the control of cholesterol homeostasis. The modulation of both pathways will have a hypocholesterolemic effect.

Various epidemiological studies and meta-analyses have shown that the use of statins reduces the risk of PCa mortality [138] and, more importantly, decreases the risks associated with the development of advanced PCa [139] to present aggressive pathological features in histological analysis of prostatectomy specimens [140] or to develop distant metastasis in patients who were diagnosed with non-metastatic PCa [141]. A decrease in the time of response to ADT has also been reported in patients with hypercholesterolemia. Conversely, statins delay the emergence of CRPC in ADT treated patients [142]. However, it should be kept in mind that statins have numerous side effects.

Since the primary use of statins in PCa therapy is still controversial, the development of new selective liver X receptor modulators (SLiMs, [143]) is theoretically a good option to regulate the intra-prostatic levels of cholesterol. These tissue-specific LXR agonists would modulate intracellular levels of cholesterol in prostate tissue, be specific for each LXR isoform, and prevent any highly adverse side effect. Such a specific SLiM, GW6340, has already been developed. It promotes macrophage reverse cholesterol transport in vivo and thus exerts an anti-atherogenic effect without side effects linked to hepatic LXRs activation like elevated plasma triglycerides [144]. As LXR $\alpha$ seems to be the isoform responsible for the hepatic adverse effects observed upon pan-LXRs activation, the development of LXR $\beta$ isoform-specific agonists actually mobilizes intense efforts from researchers. Currently, many molecules are under development [145]. Recently, BMS-852927, a novel partial LXR $\beta$-selective compound, was successfully tested in healthy human volunteers in a phase 1 ascending-dose study [146]. This study reported an increase in plasma and hepatic lipids and a decrease in circulating neutrophils in mice that was not observed in monkeys. These findings highlight the greatest difficulty in drug discovery to predict clinical responses in animal models. To date, RGX-104, a LXR $\beta$-selective agonist, is currently being tested in patients with advanced solid malignancies and lymphoma (ClinicalTrials.gov Identifier: NCT02922764). Expected effects of this molecule are a stimulation of antitumor immunity and an inhibitory action on angiogenesis. Likewise, Segala et al. showed that dendrogenin A is a natural specific activator of LXR usable in the treatment of cancers [137]. 
As the development of selective LXR agonists and in vitro/in vivo test is ongoing, the safe and effective use of SLiMs appears to will be promising notably for prostate cancer treatment, as well as other steroid-dependent tumors. Given the heterogeneity of the mechanisms of emergence of castration-resistance, the focus of interest should be combinatorial treatment in cancer therapeutic. SLiMs may be used in combination with current standard of care for the treatment of advanced $\mathrm{PCa} / \mathrm{mCRPC}$, like ADT, chemotherapy, or immunotherapy to potentiate their effects or to target multiple cancer-associated pathways and to reduce the risk of resistance development overall. Another benefit of combinatorial therapy is to diminish doses of administrated drugs and, likewise, to reduce deleterious side effect. In a xenograft mouse model of melanoma, combining LXR agonist treatment to frontline chemotherapy (dacarbazine) has shown a synergistic effect in reducing tumor growth [136]. This seems to be a direction for the future.

Funding: Funding was provided by the Région Auvergne-Rhône-Alpes, Fond Européen de Développement Régional (FEDER), Association de Recherche sur les Tumeurs Prostatiques (ARTP), Fondation ARC, Ligue contre le Cancer, and AAP Plan Cancer Environnement 2016 for SB-JMAL lab. The funders had no role in data collection and analysis, decision to publish, or preparation of the manuscript.

Acknowledgments: We are deeply grateful to James Wilmouth (GReD Lab) for his help in editing the manuscript.

Conflicts of Interest: The authors declare no conflict of interest.

\section{Abbreviations}

$\begin{array}{ll}\text { ABCA1/G1 } & \text { ATP-binding cassette A1/G1 } \\ \text { ADT } & \text { androgen deprivation therapy } \\ \text { AF1/2 } & \text { activating function 1/2 } \\ \text { AR } & \text { androgen receptor } \\ \text { COX2 } & \text { cyclooxygenase } 2 \\ \text { DHT } & \text { dihydrotestosterone } \\ \text { CRPC } & \text { castration-resistant prostate cancer } \\ \text { mCRPC } & \text { metastatic CRPC } \\ \text { ER } & \text { estrogen receptor } \\ \text { EST } & \text { estrogen sulfotransferase } \\ \text { EZH2 } & \text { enhancer of Zeste homolog 2 } \\ \text { Her-2/neu } & \text { receptor tyrosine-protein kinase erbB-2 } \\ \text { HMGCR } & \text { hydroxy-3-methylglutaryl-coenzyme A reductase } \\ \text { IDOL } & \text { inducible degrader of the LDL receptor } \\ \text { iNOS } & \text { inducible nitric oxide synthase } \\ \text { JAK/STAT } & \text { Janus kinase/signal transducers and activators of transcription } \\ \text { LDLR } & \text { LDL receptor } \\ \text { LXR } & \text { liver } X \text { receptor } \\ \text { MAPK } & \text { mitogen-activated protein kinases } \\ \text { MSMB } & \text { beta-microseminoprotein } \\ \text { NKX3.1 } & \text { homeobox protein Nkx-3.1 } \\ \text { NR } & \text { nuclear receptor } \\ \text { PCa } & \text { prostate cancer } \\ \text { PI3K } & \text { phosphoinositide 3-kinase } \\ \text { PSA } & \text { prostate specific antigen } \\ \text { RXR } & \text { retinoid X receptor } \\ \text { SOCS3 } & \text { suppressor of cytokine signaling 3 } \\ \text { SR5A2 } & \text { 5 } \alpha \text {-reductase type 2 } \\ \text { SREBP } & \text { sterol response element binding protein } \\ \text { SLiMs } & \text { selective liver X receptor modulators } \\ \text { SULT2A1 } & \text { sulfotransferase family 2A member 1 } \\ \text { VEGF } & \text { vascular endothelial growth factor } \\ \text { Wnt } & \text { Wingless / Integrated } \\ & \end{array}$




\section{References}

1. Bostwick, D.G.; Burke, H.B.; Djakiew, D.; Euling, S.; Ho, S.; Landolph, J.; Morrison, H.; Sonawane, B.; Shifflett, T.; Waters, D.J.; et al. Human prostate cancer risk factors. Cancer 2004, 101, 2371-2490. [CrossRef] [PubMed]

2. Hsing, A.W.; Chu, L.W.; Stanczyk, F.Z. Androgen and prostate cancer: Is the hypothesis dead? Cancer Epidemiol. Biomark. 2008, 17, 2525-2530. [CrossRef] [PubMed]

3. Härkönen, P.L.; Mäkelä, S.I. Role of estrogens in development of prostate cancer. J. Steroid Biochem. Mol. Biol. 2004, 92, 297-305. [CrossRef] [PubMed]

4. Prins, G.S.; Korach, K.S. The role of estrogens and estrogen receptors in normal prostate growth and disease. Steroids 2008, 73, 233-244. [CrossRef] [PubMed]

5. Evans, R.M.; Mangelsdorf, D.J. Nuclear Receptors, RXR, and the Big Bang. Cell 2014, 157, 255-266. [CrossRef] [PubMed]

6. McKenna, N.J. Research Resources for Nuclear Receptor Signaling Pathways. Mol. Pharmacol. 2016, 90, 153-159. [CrossRef] [PubMed]

7. Helsen, C.; Claessens, F. Looking at nuclear receptors from a new angle. Mol. Cell. Endocrinol. 2014, 382, 97-106. [CrossRef] [PubMed]

8. Huggins, C.; Hodges, C.V. Studies on Prostatic Cancer. I. The Effect of Castration, of Estrogen and of Androgen Injection on Serum Phosphatases in Metastatic Carcinoma of the Prostate. Cancer Res. 1941, 1, 293-297. [CrossRef]

9. Bonkhoff, H. Estrogen receptor signaling in prostate cancer: Implications for carcinogenesis and tumor progression. Prostate 2018, 78, 2-10. [CrossRef] [PubMed]

10. Maqdasy, S.; Trousson, A.; Tauveron, I.; Volle, D.H.; Baron, S.; Lobaccaro, J.-M.A. Once and for all, LXR $\alpha$ and LXR $\beta$ are gatekeepers of the endocrine system. Mol. Aspects Med. 2016, 49, 31-46. [CrossRef] [PubMed]

11. De Boussac, H.; Pommier, A.J.; Dufour, J.; Trousson, A.; Caira, F.; Volle, D.H.; Baron, S.; Lobaccaro, J.-M.A. LXR, prostate cancer and cholesterol: The Good, the Bad and the Ugly. Am. J. Cancer Res. 2013, 3, 58-69. [PubMed]

12. Dufour, J.; Pommier, A.; Alves, G.; de Boussac, H.; Lours-Calet, C.; Volle, D.H.; Lobaccaro, J.-M.A.; Baron, S. Lack of Liver X Receptors Leads to Cell Proliferation in a Model of Mouse Dorsal Prostate Epithelial Cell. PLoS ONE 2013, 8, e58876. [CrossRef] [PubMed]

13. Pommier, A.J.C.; Alves, G.; Viennois, E.; Bernard, S.; Communal, Y.; Sion, B.; Marceau, G.; Damon, C.; Mouzat, K.; Caira, F.; et al. Liver X Receptor activation downregulates AKT survival signaling in lipid rafts and induces apoptosis of prostate cancer cells. Oncogene 2010, 29, 2712-2723. [CrossRef] [PubMed]

14. Abdelgadir, S.E.; Connolly, P.B.; Resko, J.A. Androgen binding in peripheral tissues of fetal rhesus macaques: Effects of androgen metabolism in liver. J. Steroid Biochem. Mol. Biol. 1990, 37, 545-551. [CrossRef]

15. Heinlein, C.A.; Chang, C. The Roles of Androgen Receptors and Androgen-Binding Proteins in Nongenomic Androgen Actions. Mol. Endocrinol. 2002, 16, 2181-2187. [CrossRef] [PubMed]

16. Yeh, S.; Tsai, M.-Y.; Xu, Q.; Mu, X.-M.; Lardy, H.; Huang, K.-E.; Lin, H.; Yeh, S.-D.; Altuwaijri, S.; Zhou, X.; et al. Generation and characterization of androgen receptor knockout (ARKO) mice: An in vivo model for the study of androgen functions in selective tissues. Proc. Natl. Acad. Sci. USA 2002, 99, 13498-13503. [CrossRef] [PubMed]

17. Cunha, G.R. The role of androgens in the epithelio-mesenchymal interactions involved in prostatic morphogenesis in embryonic mice. Anat. Rec. 1973, 175, 87-96. [CrossRef] [PubMed]

18. Lu, W.; Luo, Y.; Kan, M.; McKeehan, W.L. Fibroblast Growth Factor-10 A second candidate stromal to epithelial cell andromedin in prostate. J. Biol. Chem. 1999, 274, 12827-12834. [CrossRef] [PubMed]

19. Planz, B.; Aretz, H.T.; Wang, Q.; Tabatabaei, S.; Kirley, S.D.; Lin, C.W.; McDougal, W.S. Immunolocalization of the keratinocyte growth factor in benign and neoplastic human prostate and its relation to androgen receptor. Prostate 1999, 41, 233-242. [CrossRef]

20. Wikström, P.; Westin, P.; Stattin, P.; Damber, J.E.; Bergh, A. Early castration-induced upregulation of transforming growth factor beta1 and its receptors is associated with tumor cell apoptosis and a major decline in serum prostate-specific antigen in prostate cancer patients. Prostate 1999, 38, 268-277. [CrossRef] 
21. Bonkhoff, H.; Remberger, K. Widespread distribution of nuclear androgen receptors in the basal cell layer of the normal and hyperplastic human prostate. Virchows Arch. Pathol. Anat. Histopathol. 1993, 422, 35-38. [CrossRef]

22. Mirosevich, J.; Bentel, J.M.; Zeps, N.; Redmond, S.L.; D'Antuono, M.F.; Dawkins, H.J. Androgen receptor expression of proliferating basal and luminal cells in adult murine ventral prostate. J. Endocrinol. 1999, 162, 341-350. [CrossRef] [PubMed]

23. Berry, S.J.; Isaacs, J.T. Comparative Aspects of Prostatic Growth and Androgen Metabolism with Aging in the Dog Versus the Rat. Endocrinology 1984, 114, 511-520. [CrossRef] [PubMed]

24. English, H.F.; Kyprianou, N.; Isaacs, J.T. Relationship between DNA fragmentation and apoptosis in the programmed cell death in the rat prostate following castration. Prostate 1989, 15, 233-250. [CrossRef] [PubMed]

25. Gao, J.; Isaacs, J.T. Development of an androgen receptor-null model for identifying the initiation site for androgen stimulation of proliferation and suppression of programmed (apoptotic) death of PC-82 human prostate cancer cells. Cancer Res. 1998, 58, 3299-3306. [PubMed]

26. Gao, J.; Arnold, J.T.; Isaacs, J.T. Conversion from a paracrine to an autocrine mechanism of androgen-stimulated growth during malignant transformation of prostatic epithelial cells. Cancer Res. 2001, 61, 5038-5044. [PubMed]

27. Memarzadeh, S.; Cai, H.; Janzen, D.M.; Xin, L.; Lukacs, R.; Riedinger, M.; Zong, Y.; DeGendt, K.; Verhoeven, G.; Huang, J.; et al. Role of autonomous androgen receptor signaling in prostate cancer initiation is dichotomous and depends on the oncogenic signal. Proc. Natl. Acad. Sci. USA 2011, 108, 7962-7967. [CrossRef] [PubMed]

28. Massie, C.E.; Lynch, A.; Ramos-Montoya, A.; Boren, J.; Stark, R.; Fazli, L.; Warren, A.; Scott, H.; Madhu, B.; Sharma, N.; et al. The androgen receptor fuels prostate cancer by regulating central metabolism and biosynthesis. EMBO J. 2011, 30, 2719-2733. [CrossRef] [PubMed]

29. Jin, H.-J.; Kim, J.; Yu, J. Androgen receptor genomic regulation. Transl. Androl. Urol. 2013, 2, $157-177$. [CrossRef] [PubMed]

30. Sharma, N.L.; Massie, C.E.; Ramos-Montoya, A.; Zecchini, V.; Scott, H.E.; Lamb, A.D.; MacArthur, S.; Stark, R.; Warren, A.Y.; Mills, I.G.; et al. The androgen receptor induces a distinct transcriptional program in castration-resistant prostate cancer in man. Cancer Cell 2013, 23, 35-47. [CrossRef] [PubMed]

31. Yaşar, P.; Ayaz, G.; User, S.D.; Güpür, G.; Muyan, M. Molecular mechanism of estrogen-estrogen receptor signaling. Reprod. Med. Biol. 2017, 16, 4-20. [CrossRef] [PubMed]

32. Chen, M.; Hsu, I.; Wolfe, A.; Radovick, S.; Huang, K.; Yu, S.; Chang, C.; Messing, E.M.; Yeh, S. Defects of prostate development and reproductive system in the estrogen receptor-alpha null male mice. Endocrinology 2009, 150, 251-259. [CrossRef] [PubMed]

33. Chen, M.; Yeh, C.-R.; Chang, H.-C.; Vitkus, S.; Wen, X.-Q.; Bhowmick, N.A.; Wolfe, A.; Yeh, S. Loss of epithelial oestrogen receptor $\alpha$ inhibits oestrogen-stimulated prostate proliferation and squamous metaplasia via in vivo tissue selective knockout models. J. Pathol. 2012, 226, 17-27. [CrossRef] [PubMed]

34. Vitkus, S.; Yeh, C.-R.; Lin, H.-H.; Hsu, I.; Yu, J.; Chen, M.; Yeh, S. Distinct function of estrogen receptor $\alpha$ in smooth muscle and fibroblast cells in prostate development. Mol. Endocrinol. 2013, 27, 38-49. [CrossRef] [PubMed]

35. Leav, I.; Lau, K.M.; Adams, J.Y.; McNeal, J.E.; Taplin, M.E.; Wang, J.; Singh, H.; Ho, S.M. Comparative studies of the estrogen receptors beta and alpha and the androgen receptor in normal human prostate glands, dysplasia, and in primary and metastatic carcinoma. Am. J. Pathol. 2001, 159, 79-92. [CrossRef]

36. Lau, K.M.; LaSpina, M.; Long, J.; Ho, S.M. Expression of estrogen receptor (ER)- $\alpha$ and ER- $\beta$ in normal and malignant prostatic epithelial cells: Regulation by methylation and involvement in growth regulation. Cancer Res. 2000, 60, 3175-3182. [PubMed]

37. Royuela, M.; de Miguel, M.P.; Bethencourt, F.R.; Sánchez-Chapado, M.; Fraile, B.; Arenas, M.I.; Paniagua, R. Estrogen receptors $\alpha$ and $\beta$ in the normal, hyperplastic and carcinomatous human prostate. J. Endocrinol. 2001, 168, 447-454. [CrossRef] [PubMed]

38. Imamov, O.; Morani, A.; Shim, G.-J.; Omoto, Y.; Thulin-Andersson, C.; Warner, M.; Gustafsson, J.-A. Estrogen receptor $\beta$ regulates epithelial cellular differentiation in the mouse ventral prostate. Proc. Natl. Acad. Sci. USA 2004, 101, 9375-9380. [CrossRef] [PubMed] 
39. Latil, A.; Bièche, I.; Vidaud, D.; Lidereau, R.; Berthon, P.; Cussenot, O.; Vidaud, M. Evaluation of androgen, estrogen (ER $\alpha$ and ER $\beta$ ), and progesterone receptor expression in human prostate cancer by real-time quantitative reverse transcription-polymerase chain reaction assays. Cancer Res. 2001, 61, 1919-1926. [PubMed]

40. Bonkhoff, H.; Fixemer, T.; Hunsicker, I.; Remberger, K. Estrogen Receptor Expression in Prostate Cancer and Premalignant Prostatic Lesions. Am. J. Pathol. 1999, 155, 641-647. [CrossRef]

41. Slusarz, A.; Jackson, G.A.; Day, J.K.; Shenouda, N.S.; Bogener, J.L.; Browning, J.D.; Fritsche, K.L.; MacDonald, R.S.; Besch-Williford, C.L.; Lubahn, D.B. Aggressive prostate cancer is prevented in ER $\alpha \mathrm{KO}$ mice and stimulated in ER $\beta$ KO TRAMP mice. Endocrinology 2012, 153, 4160-4170. [CrossRef] [PubMed]

42. Mohler, J.L.; Gregory, C.W.; Ford, O.H.; Kim, D.; Weaver, C.M.; Petrusz, P.; Wilson, E.M.; French, F.S. The androgen axis in recurrent prostate cancer. Clin. Cancer Res. 2004, 10, 440-448. [CrossRef] [PubMed]

43. Ellem, S.J.; Schmitt, J.F.; Pedersen, J.S.; Frydenberg, M.; Risbridger, G.P. Local aromatase expression in human prostate is altered in malignancy. J. Clin. Endocrinol. Metab. 2004, 89, 2434-2441. [CrossRef] [PubMed]

44. Montgomery, R.B.; Mostaghel, E.A.; Vessella, R.; Hess, D.L.; Kalhorn, T.F.; Higano, C.S.; True, L.D.; Nelson, P.S. Maintenance of intratumoral androgens in metastatic prostate cancer: A mechanism for castration-resistant tumor growth. Cancer Res. 2008, 68, 4447-4454. [CrossRef] [PubMed]

45. Wang, B.; Tontonoz, P. Liver X receptors in lipid signalling and membrane homeostasis. Nat. Rev. Endocrinol. 2018, 14, 452-463. [CrossRef] [PubMed]

46. Janowski, B.A.; Willy, P.J.; Devi, T.R.; Falck, J.R.; Mangelsdorf, D.J. An oxysterol signalling pathway mediated by the nuclear receptor LXR $\alpha$. Nature 1996, 383, 728-731. [CrossRef] [PubMed]

47. Janowski, B.A.; Grogan, M.J.; Jones, S.A.; Wisely, G.B.; Kliewer, S.A.; Corey, E.J.; Mangelsdorf, D.J. Structural requirements of ligands for the oxysterol liver X receptors LXR $\alpha$ and LXR $\beta$. Proc. Natl. Acad. Sci. USA 1999, 96, 266-271. [CrossRef] [PubMed]

48. Peet, D.J.; Turley, S.D.; Ma, W.; Janowski, B.A.; Lobaccaro, J.M.; Hammer, R.E.; Mangelsdorf, D.J. Cholesterol and bile acid metabolism are impaired in mice lacking the nuclear oxysterol receptor LXR $\alpha$. Cell 1998, 93, 693-704. [CrossRef]

49. Viennois, E.; Esposito, T.; Dufour, J.; Pommier, A.; Fabre, S.; Kemeny, J.-L.; Guy, L.; Morel, L.; Lobaccaro, J.-M.; Baron, S. LXR $\alpha$ Regulates the Androgen Response in Prostate Epithelium. Endocrinology 2012, 153, 3211-3223. [CrossRef] [PubMed]

50. Fukuchi, J.; Hiipakka, R.A.; Kokontis, J.M.; Hsu, S.; Ko, A.L.; Fitzgerald, M.L.; Liao, S. Androgenic suppression of ATP-binding cassette transporter A1 expression in LNCaP human prostate cancer cells. Cancer Res. 2004, 64, 7682-7685. [CrossRef] [PubMed]

51. Fukuchi, J.; Kokontis, J.M.; Hiipakka, R.A.; Chuu, C.; Liao, S. Antiproliferative Effect of Liver X Receptor Agonists on LNCaP Human Prostate Cancer Cells. Cancer Res. 2004, 64, 7686-7689. [CrossRef] [PubMed]

52. Chuu, C.; Hiipakka, R.A.; Kokontis, J.M.; Fukuchi, J.; Chen, R.-Y.; Liao, S. Inhibition of tumor growth and progression of LNCaP prostate cancer cells in athymic mice by androgen and liver $\mathrm{X}$ receptor agonist. Cancer Res. 2006, 66, 6482-6486. [CrossRef] [PubMed]

53. Taylor, B.S.; Schultz, N.; Hieronymus, H.; Gopalan, A.; Xiao, Y.; Carver, B.S.; Arora, V.K.; Kaushik, P.; Cerami, E.; Reva, B.; et al. Integrative Genomic Profiling of Human Prostate Cancer. Cancer Cell 2010, 18, 11-22. [CrossRef] [PubMed]

54. Puhr, M.; Santer, F.R.; Neuwirt, H.; Marcias, G.; Hobisch, A.; Culig, Z. SOCS-3 antagonises the proliferative and migratory effects of fibroblast growth factor-2 in prostate cancer by inhibition of p44/p42 MAPK signalling. Endocr. Relat. Cancer 2010, 17, 525-538. [CrossRef] [PubMed]

55. Fu, W.; Yao, J.; Huang, Y.; Li, Q.; Li, W.; Chen, Z.; He, F.; Zhou, Z.; Yan, J. LXR Agonist Regulates the Carcinogenesis of PCa via the SOCS3 Pathway. Cell. Physiol. Biochem. 2014, 33, 195-204. [CrossRef] [PubMed]

56. Xiong, H.; Zhang, Y.; Chen, S.; Ni, Z.; He, J.; Li, X.; Li, B.; Zhao, K.; Yang, F.; Zeng, Y.; et al. Induction of SOCS3 by liver $X$ receptor suppresses the proliferation of hepatocellular carcinoma cells. Oncotarget 2017, 8, 64083-64094. [CrossRef] [PubMed]

57. Youlin, K.; Li, Z.; Weiyang, H.; Jian, K.; Siming, L.; Xin, G. Liver X receptor activation inhibits PC-3 prostate cancer cells via the beta-catenin pathway. Pathol. Res. Pract. 2017, 213, 267-270. [CrossRef] [PubMed] 
58. Pommier, A.J.C.; Dufour, J.; Alves, G.; Viennois, E.; de Boussac, H.; Trousson, A.; Volle, D.H.; Caira, F.; Val, P.; Arnaud, P.; et al. Liver $X$ receptors protect from development of prostatic intra-epithelial neoplasia in mice. PLoS Genet. 2013, 9, e1003483. [CrossRef] [PubMed]

59. Varambally, S.; Dhanasekaran, S.M.; Zhou, M.; Barrette, T.R.; Kumar-Sinha, C.; Sanda, M.G.; Ghosh, D.; Pienta, K.J.; Sewalt, R.G.A.B.; Otte, A.P.; et al. The polycomb group protein EZH2 is involved in progression of prostate cancer. Nature 2002, 419, 624-629. [CrossRef] [PubMed]

60. Tamae, D.; Mostaghel, E.; Montgomery, B.; Nelson, P.S.; Balk, S.P.; Kantoff, P.W.; Taplin, M.-E.; Penning, T.M. The DHEA-sulfate depot following P450c17 inhibition supports the case for AKR1C3 inhibition in high risk localized and advanced castration resistant prostate cancer. Chem. Biol. Interact. 2015, 234, 332-338. [CrossRef] [PubMed]

61. Pasqualini, J.R. Estrogen sulfotransferases in breast and endometrial cancers. Ann. N. Y. Acad. Sci. 2009, 1155, 88-98. [CrossRef] [PubMed]

62. Lee, J.H.; Gong, H.; Khadem, S.; Lu, Y.; Gao, X.; Li, S.; Zhang, J.; Xie, W. Androgen deprivation by activating the liver $X$ receptor. Endocrinology 2008, 149, 3778-3788. [CrossRef] [PubMed]

63. Gong, H.; Guo, P.; Zhai, Y.; Zhou, J.; Uppal, H.; Jarzynka, M.J.; Song, W.-C.; Cheng, S.-Y.; Xie, W. Estrogen deprivation and inhibition of breast cancer growth in vivo through activation of the orphan nuclear receptor liver X receptor. Mol. Endocrinol. 2007, 21, 1781-1790. [CrossRef] [PubMed]

64. Song, W.C. Biochemistry and reproductive endocrinology of estrogen sulfotransferase. Ann. N. Y. Acad. Sci. 2001, 948, 43-50. [CrossRef] [PubMed]

65. Dozmorov, M.G.; Hurst, R.E.; Culkin, D.J.; Kropp, B.P.; Frank, M.B.; Osban, J.; Penning, T.M.; Lin, H.-K. Unique patterns of molecular profiling between human prostate cancer LNCaP and PC-3 cells. Prostate 2009, 69, 1077-1090. [CrossRef] [PubMed]

66. Sekine, Y.; Demosky, S.J.; Stonik, J.A.; Furuya, Y.; Koike, H.; Suzuki, K.; Remaley, A.T. High-density lipoprotein induces proliferation and migration of human prostate androgen-independent cancer cells by an ABCA1-dependent mechanism. Mol. Cancer Res. 2010, 8, 1284-1294. [CrossRef] [PubMed]

67. Füllhase, C.; Schneider, M.P. 5- $\alpha$-Reductase Inhibitors and Combination Therapy. Urol. Clin. 2016, 43, 325-336. [CrossRef] [PubMed]

68. Kim, H.-J.; Andersson, L.C.; Bouton, D.; Warner, M.; Gustafsson, J.-A. Stromal growth and epithelial cell proliferation in ventral prostates of liver X receptor knockout mice. Proc. Natl. Acad. Sci. USA 2009, 106, 558-563. [CrossRef] [PubMed]

69. Tsui, K.-H.; Chung, L.-C.; Feng, T.-H.; Lee, T.-Y.; Chang, P.-L.; Chen, W.-T.; Juang, H.-H. Divergent effect of liver $\mathrm{X}$ receptor agonists on prostate-specific antigen expression is dependent on androgen receptor in prostate carcinoma cells. Prostate 2015, 75, 603-615. [CrossRef] [PubMed]

70. Lundholm, L.; Moverare, S.; Steffensen, K.R.; Nilsson, M.; Otsuki, M.; Ohlsson, C.; Gustafsson, J.A.; Dahlman-Wright, K. Gene expression profiling identifies liver $X$ receptor $\alpha$ as an estrogen-regulated gene in mouse adipose tissue. J. Mol. Endocrinol. 2004, 32, 879-892. [CrossRef] [PubMed]

71. Kramer, P.R.; Wray, S. 17- $\beta$-estradiol regulates expression of genes that function in macrophage activation and cholesterol homeostasis. J. Steroid Biochem. Mol. Biol. 2002, 81, 203-216. [CrossRef]

72. Delfosse, V.; le Maire, A.; Balaguer, P.; Bourguet, W. A structural perspective on nuclear receptors as targets of environmental compounds. Acta Pharmacol. Sin. 2015, 36, 88-101. [CrossRef] [PubMed]

73. Schulze, A.; Harris, A.L. How cancer metabolism is tuned for proliferation and vulnerable to disruption. Nature 2012, 491, 364-373. [CrossRef] [PubMed]

74. Warburg, O. On respiratory impairment in cancer cells. Science 1956, 124, 269-270. [PubMed]

75. Mycielska, M.E.; Patel, A.; Rizaner, N.; Mazurek, M.P.; Keun, H.; Patel, A.; Ganapathy, V.; Djamgoz, M.B.A. Citrate transport and metabolism in mammalian cells. BioEssays 2009, 31, 10-20. [CrossRef] [PubMed]

76. Swinnen, J.V.; Roskams, T.; Joniau, S.; van Poppel, H.; Oyen, R.; Baert, L.; Heyns, W.; Verhoeven, G. Overexpression of fatty acid synthase is an early and common event in the development of prostate cancer. Int. J. Cancer 2002, 98, 19-22. [CrossRef] [PubMed]

77. Swyer, G.I.M. The Cholesterol Content of Normal and Enlarged Prostates. Cancer Res. 1942, 2, 372-375.

78. White, C.P. On the occurrence of crystals in tumours. J. Pathol. Bacteriol. 1909, 13, 3-10. [CrossRef]

79. Yue, S.; Li, J.; Lee, S.-Y.; Lee, H.J.; Shao, T.; Song, B.; Cheng, L.; Masterson, T.A.; Liu, X.; Ratliff, T.L.; et al. Cholesteryl Ester Accumulation Induced by PTEN Loss and PI3K/AKT Activation Underlies Human Prostate Cancer Aggressiveness. Cell Metab. 2014, 19, 393-406. [CrossRef] [PubMed] 
80. Wettstein, M.S.; Saba, K.; Umbehr, M.H.; Murtola, T.J.; Fankhauser, C.D.; Adank, J.-P.; Hofmann, M.; Sulser, T.; Hermanns, T.; Moch, H.; et al. Prognostic Role of Preoperative Serum Lipid Levels in Patients Undergoing Radical Prostatectomy for Clinically Localized Prostate Cancer. Prostate 2017, 77, 549-556. [CrossRef] [PubMed]

81. Alfaqih, M.A.; Allott, E.H.; Hamilton, R.J.; Freeman, M.R.; Freedland, S.J. The current evidence on statin use and prostate cancer prevention: Are we there yet? Nat. Rev. Urol. 2017, 14, 107-119. [CrossRef] [PubMed]

82. Krycer, J.R.; Brown, A.J. Cross-talk between the androgen receptor and the liver $\mathrm{X}$ receptor: Implications for cholesterol homeostasis. J. Biol. Chem. 2011, 286, 20637-20647. [CrossRef] [PubMed]

83. Cariello, M.; Ducheix, S.; Maqdasy, S.; Baron, S.; Moschetta, A.; Lobaccaro, J. LXRs, SHP and FXR in prostate cancer: Enemies or Ménage-à-quatre with AR? Nucl. Recpt. Signal. 2018, in press.

84. Morris, M.D.; Chaikoff, I.L. The origin of cholesterol in liver, small intestine, adrenal gland, and testis of the rat: Dietary versus endogenous contributions. J. Biol. Chem. 1959, 234, 1095-1097. [PubMed]

85. Schaffner, C.P. Prostatic cholesterol metabolism: Regulation and alteration. Prog. Clin. Biol. Res. 1981, 75A, 279-324. [PubMed]

86. Michaud, D.S.; Augustsson, K.; Rimm, E.B.; Stampfer, M.J.; Willet, W.C.; Giovannucci, E. A prospective study on intake of animal products and risk of prostate cancer. Cancer Causes Control 2001, 12, 557-567. [CrossRef] [PubMed]

87. De Marzo, A.M.; Platz, E.A.; Sutcliffe, S.; Xu, J.; Grönberg, H.; Drake, C.G.; Nakai, Y.; Isaacs, W.B.; Nelson, W.G. Inflammation in prostate carcinogenesis. Nat. Rev. Cancer 2007, 7, 256-269. [CrossRef] [PubMed]

88. Aaltoma, S.H.; Lipponen, P.K.; Kosma, V.M. Inducible nitric oxide synthase (iNOS) expression and its prognostic value in prostate cancer. Anticancer Res. 2001, 21, 3101-3106. [PubMed]

89. Tsai, C.-S.; Chen, F.-H.; Wang, C.-C.; Huang, H.-L.; Jung, S.-M.; Wu, C.-J.; Lee, C.-C.; McBride, W.H.; Chiang, C.-S.; Hong, J.-H. Macrophages From Irradiated Tumors Express Higher Levels of iNOS, Arginase-I and COX-2, and Promote Tumor Growth. Int. J. Radiat. Oncol. 2007, 68, 499-507. [CrossRef] [PubMed]

90. Twillie, D.A.; Eisenberger, M.A.; Carducci, M.A.; Hseih, W.-S.; Kim, W.Y.; Simons, J.W. Interleukin-6: A candidate mediator of human prostate cancer morbidity. Urology 1995, 45, 542-549. [CrossRef]

91. Siegsmund, M.J.; Yamazaki, H.; Pastan, I. Interleukin 6 receptor mRNA in prostate carcinomas and benign prostate hyperplasia. J. Urol. 1994, 151, 1396-1399. [CrossRef]

92. Castrillo, A.; Joseph, S.B.; Vaidya, S.A.; Haberland, M.; Fogelman, A.M.; Cheng, G.; Tontonoz, P. Crosstalk between LXR and toll-like receptor signaling mediates bacterial and viral antagonism of cholesterol metabolism. Mol. Cell 2003, 12, 805-816. [CrossRef]

93. Joseph, S.B.; Castrillo, A.; Laffitte, B.A.; Mangelsdorf, D.J.; Tontonoz, P. Reciprocal regulation of inflammation and lipid metabolism by liver $X$ receptors. Nat. Med. 2003, 9, 213-219. [CrossRef] [PubMed]

94. Wang, Q.; Ma, X.; Chen, Y.; Zhang, L.; Jiang, M.; Li, X.; Xiang, R.; Miao, R.; Hajjar, D.P.; Duan, Y.; et al. Identification of interferon- $\gamma$ as a new molecular target of liver $X$ receptor. Biochem. J. 2014, 459, 345-354. [CrossRef] [PubMed]

95. Labrecque, L.; Royal, I.; Surprenant, D.S.; Patterson, C.; Gingras, D.; Béliveau, R. Regulation of Vascular Endothelial Growth Factor Receptor-2 Activity by Caveolin-1 and Plasma Membrane Cholesterol. Mol. Biol. Cell 2003, 14, 334-347. [CrossRef] [PubMed]

96. Noghero, A.; Perino, A.; Seano, G.; Saglio, E.; Lo Sasso, G.; Veglio, F.; Primo, L.; Hirsch, E.; Bussolino, F.; Morello, F. Liver $\mathrm{X}$ receptor activation reduces angiogenesis by impairing lipid raft localization and signaling of vascular endothelial growth factor receptor-2. Arterioscler. Thromb. Vasc. Biol. Thromb. Vasc. Biol. 2012, 32, 2280-2288. [CrossRef] [PubMed]

97. Lai, C.-J.; Cheng, H.-C.; Lin, C.-Y.; Huang, S.-H.; Chen, T.-H.; Chung, C.-J.; Chang, C.-H.; Wang, H.-D.; Chuu, C.-P. Activation of liver X receptor suppresses angiogenesis via induction of ApoD. FASEB J. $2017,31$. [CrossRef] [PubMed]

98. Albertsen, P.C. Observational studies and the natural history of screen-detected prostate cancer. Curr. Opin. Urol. 2015, 25, 232-237. [CrossRef] [PubMed]

99. Siegel, R.L.; Miller, K.D.; Jemal, A. Cancer statistics, 2016. CA. Cancer J. Clin. 2016, 66, 7-30. [CrossRef] [PubMed]

100. James, N.D.; Sydes, M.R.; Clarke, N.W.; Mason, M.D.; Dearnaley, D.P.; Spears, M.R.; Ritchie, A.W.S.; Parker, C.C.; Russell, J.M.; Attard, G.; et al. Addition of docetaxel, zoledronic acid, or both to first-line long-term hormone therapy in prostate cancer (STAMPEDE): Survival results from an adaptive, multiarm, multistage, platform randomised controlled trial. Lancet Lond. Engl. 2016, 387, 1163-1177. [CrossRef] 
101. Sweeney, C.J.; Chen, Y.-H.; Carducci, M.; Liu, G.; Jarrard, D.F.; Eisenberger, M.; Wong, Y.-N.; Hahn, N.; Kohli, M.; Cooney, M.M.; et al. Chemohormonal Therapy in Metastatic Hormone-Sensitive Prostate Cancer. N. Engl. J. Med. 2015, 373, 737-746. [CrossRef] [PubMed]

102. Klotz, L.; Boccon-Gibod, L.; Shore, N.D.; Andreou, C.; Persson, B.-E.; Cantor, P.; Jensen, J.-K.; Olesen, T.K.; Schröder, F.H. The efficacy and safety of degarelix: A 12-month, comparative, randomized, open-label, parallel-group phase III study in patients with prostate cancer. BJU Int. 2008, 102, 1531-1538. [CrossRef] [PubMed]

103. Attard, G.; Reid, A.H.M.; A'Hern, R.; Parker, C.; Oommen, N.B.; Folkerd, E.; Messiou, C.; Molife, L.R.; Maier, G.; Thompson, E.; et al. Selective Inhibition of CYP17 With Abiraterone Acetate Is Highly Active in the Treatment of Castration-Resistant Prostate Cancer. J. Clin. Oncol. 2009, 27, 3742-3748. [CrossRef] [PubMed]

104. Chang, K.-H.; Li, R.; Kuri, B.; Lotan, Y.; Roehrborn, C.G.; Liu, J.; Vessella, R.; Nelson, P.S.; Kapur, P.; Guo, X.; et al. A gain-of-function mutation in DHT synthesis in castration-resistant prostate cancer. Cell 2013, 154, 1074-1084. [CrossRef] [PubMed]

105. Hamid, A.R.A.H.; Pfeiffer, M.J.; Verhaegh, G.W.; Schaafsma, E.; Brandt, A.; Sweep, F.C.G.J.; Sedelaar, J.P.M.; Schalken, J.A. Aldo-keto reductase family 1 member C3 (AKR1C3) is a biomarker and therapeutic target for castration-resistant prostate cancer. Mol. Med. Camb. Mass 2013, 18, 1449-1455. [CrossRef] [PubMed]

106. Tran, C.; Ouk, S.; Clegg, N.J.; Chen, Y.; Watson, P.A.; Arora, V.; Wongvipat, J.; Smith-Jones, P.M.; Yoo, D.; Kwon, A.; et al. Development of a Second-Generation Antiandrogen for Treatment of Advanced Prostate Cancer. Science 2009, 324, 787-790. [CrossRef] [PubMed]

107. Sharifi, N.; Dahut, W.L.; Steinberg, S.M.; Figg, W.D.; Tarassoff, C.; Arlen, P.; Gulley, J.L. A retrospective study of the time to clinical endpoints for advanced prostate cancer. BJU Int. 2005, 96, 985-989. [CrossRef] [PubMed]

108. Cornford, P.; Bellmunt, J.; Bolla, M.; Briers, E.; de Santis, M.; Gross, T.; Henry, A.M.; Joniau, S.; Lam, T.B.; Mason, M.D.; et al. EAU-ESTRO-SIOG Guidelines on Prostate Cancer. Part II: Treatment of Relapsing, Metastatic, and Castration-Resistant Prostate Cancer. Eur. Urol. 2017, 71, 630-642. [CrossRef] [PubMed]

109. Smith, M.R.; Kabbinavar, F.; Saad, F.; Hussain, A.; Gittelman, M.C.; Bilhartz, D.L.; Wynne, C.; Murray, R.; Zinner, N.R.; Schulman, C.; et al. Natural history of rising serum prostate-specific antigen in men with castrate nonmetastatic prostate cancer. J. Clin. Oncol. 2005, 23, 2918-2925. [CrossRef] [PubMed]

110. Robinson, D.; van Allen, E.M.; Wu, Y.-M.; Schultz, N.; Lonigro, R.J.; Mosquera, J.-M.; Montgomery, B.; Taplin, M.-E.; Pritchard, C.C.; Attard, G.; et al. Integrative Clinical Genomics of Advanced Prostate Cancer. Cell 2015, 162, 454. [CrossRef] [PubMed]

111. Visakorpi, T.; Hyytinen, E.; Koivisto, P.; Tanner, M.; Keinänen, R.; Palmberg, C.; Palotie, A.; Tammela, T.; Isola, J.; Kallioniemi, O.-P. In vivo amplification of the androgen receptor gene and progression of human prostate cancer. Nat. Genet. 1995, 9, 401-406. [CrossRef] [PubMed]

112. Chen, C.D.; Welsbie, D.S.; Tran, C.; Baek, S.H.; Chen, R.; Vessella, R.; Rosenfeld, M.G.; Sawyers, C.L. Molecular determinants of resistance to antiandrogen therapy. Nat. Med. 2004, 10, 33-39. [CrossRef] [PubMed]

113. Komiya, A.; Yasuda, K.; Watanabe, A.; Fujiuchi, Y.; Tsuzuki, T.; Fuse, H. The prognostic significance of loss of the androgen receptor and neuroendocrine differentiation in prostate biopsy specimens among castration-resistant prostate cancer patients. Mol. Clin. Oncol. 2013, 1, 257-262. [CrossRef] [PubMed]

114. Waltering, K.K.; Urbanucci, A.; Visakorpi, T. Androgen receptor (AR) aberrations in castration-resistant prostate cancer. Mol. Cell. Endocrinol. 2012, 360, 38-43. [CrossRef] [PubMed]

115. Miyamoto, H.; Yeh, S.; Wilding, G.; Chang, C. Promotion of agonist activity of antiandrogens by the androgen receptor coactivator, ARA70, in human prostate cancer DU145 cells. Proc. Natl. Acad. Sci. USA 1998, 95, 7379-7384. [CrossRef] [PubMed]

116. Gerhardt, J.; Montani, M.; Wild, P.; Beer, M.; Huber, F.; Hermanns, T.; Müntener, M.; Kristiansen, G. FOXA1 Promotes Tumor Progression in Prostate Cancer and Represents a Novel Hallmark of Castration-Resistant Prostate Cancer. Am. J. Pathol. 2012, 180, 848-861. [CrossRef] [PubMed]

117. Gregory, C.W.; He, B.; Johnson, R.T.; Ford, O.H.; Mohler, J.L.; French, F.S.; Wilson, E.M. A Mechanism for Androgen Receptor-mediated Prostate Cancer Recurrence after Androgen Deprivation Therapy. Cancer Res. 2001, 61, 4315-4319. [PubMed] 
118. Xu, K.; Wu, Z.J.; Groner, A.C.; He, H.H.; Cai, C.; Lis, R.T.; Wu, X.; Stack, E.C.; Loda, M.; Liu, T.; et al. EZH2 oncogenic activity in castration-resistant prostate cancer cells is Polycomb-independent. Science 2012, 338, 1465-1469. [CrossRef] [PubMed]

119. Yepuru, M.; Wu, Z.; Kulkarni, A.; Yin, F.; Barrett, C.M.; Kim, J.; Steiner, M.S.; Miller, D.D.; Dalton, J.T.; Narayanan, R. Steroidogenic enzyme AKR1C3 is a novel androgen receptor-selective coactivator that promotes prostate cancer growth. Clin. Cancer Res. 2013, 19, 5613-5625. [CrossRef] [PubMed]

120. Culig, Z.; Hobisch, A.; Cronauer, M.V.; Radmayr, C.; Trapman, J.; Hittmair, A.; Bartsch, G.; Klocker, H. Androgen receptor activation in prostatic tumor cell lines by insulin-like growth factor-I, keratinocyte growth factor, and epidermal growth factor. Cancer Res. 1994, 54, 5474-5478. [CrossRef] [PubMed]

121. Signoretti, S.; Montironi, R.; Manola, J.; Altimari, A.; Tam, C.; Bubley, G.; Balk, S.; Thomas, G.; Kaplan, I.; Hlatky, L.; et al. Her-2-neu Expression and Progression Toward Androgen Independence in Human Prostate Cancer. JNCI J. Natl. Cancer Inst. 2000, 92, 1918-1925. [CrossRef] [PubMed]

122. Osman, I.; Scher, H.I.; Drobnjak, M.; Verbel, D.; Morris, M.; Agus, D.; Ross, J.S.; Cordon-Cardo, C. HER-2/neu (p185neu) Protein Expression in the Natural or Treated History of Prostate Cancer. Clin. Cancer Res. 2001, 7, 2643-2647. [PubMed]

123. Yeh, S.; Lin, H.-K.; Kang, H.-Y.; Thin, T.H.; Lin, M.-F.; Chang, C. From HER2/Neu signal cascade to androgen receptor and its coactivators: A novel pathway by induction of androgen target genes through MAP kinase in prostate cancer cells. Proc. Natl. Acad. Sci. USA 1999, 96, 5458-5463. [CrossRef] [PubMed]

124. Mellinghoff, I.K.; Vivanco, I.; Kwon, A.; Tran, C.; Wongvipat, J.; Sawyers, C.L. HER2/neu kinase-dependent modulation of androgen receptor function through effects on DNA binding and stability. Cancer Cell 2004, 6, 517-527. [CrossRef] [PubMed]

125. Labrie, F. Adrenal androgens and intracrinology. Semin. Reprod. Med. 2004, 22, 299-309. [CrossRef] [PubMed]

126. Mitsiades, N.; Sung, C.C.; Schultz, N.; Danila, D.C.; He, B.; Eedunuri, V.K.; Fleisher, M.; Sander, C.; Sawyers, C.L.; Scher, H.I. Distinct patterns of dysregulated expression of enzymes involved in androgen synthesis and metabolism in metastatic prostate cancer tumors. Cancer Res. 2012, 72, 6142-6152. [CrossRef] [PubMed]

127. De Bono, J.S.; Oudard, S.; Ozguroglu, M.; Hansen, S.; Machiels, J.-P.; Kocak, I.; Gravis, G.; Bodrogi, I.; Mackenzie, M.J.; Shen, L.; et al. Prednisone plus cabazitaxel or mitoxantrone for metastatic castration-resistant prostate cancer progressing after docetaxel treatment: A randomised open-label trial. Lancet 2010, 376, 1147-1154. [CrossRef]

128. Bubendorf, L.; Schöpfer, A.; Wagner, U.; Sauter, G.; Moch, H.; Willi, N.; Gasser, T.C.; Mihatsch, M.J. Metastatic patterns of prostate cancer: An autopsy study of 1589 patients. Hum. Pathol. 2000, 31, 578-583. [CrossRef] [PubMed]

129. Weinfurt, K.P.; Li, Y.; Castel, L.D.; Saad, F.; Timbie, J.W.; Glendenning, G.A.; Schulman, K.A. The significance of skeletal-related events for the health-related quality of life of patients with metastatic prostate cancer. Ann. Oncol. 2005, 16, 579-584. [CrossRef] [PubMed]

130. Parker, C.; Nilsson, S.; Heinrich, D.; Helle, S.I.; O’Sullivan, J.M.; Fosså, S.D.; Chodacki, A.; Wiechno, P.; Logue, J.; Seke, M.; et al. Alpha emitter radium-223 and survival in metastatic prostate cancer. N. Engl. J. Med. 2013, 369, 213-223. [CrossRef] [PubMed]

131. Saad, F.; Gleason, D.M.; Murray, R.; Tchekmedyian, S.; Venner, P.; Lacombe, L.; Chin, J.L.; Vinholes, J.J.; Goas, J.A.; Zheng, M. Long-term efficacy of zoledronic acid for the prevention of skeletal complications in patients with metastatic hormone-refractory prostate cancer. J. Natl. Cancer Inst. 2004, 96, 879-882. [CrossRef] [PubMed]

132. Smith, M.R.; Saad, F.; Coleman, R.; Shore, N.; Fizazi, K.; Tombal, B.; Miller, K.; Sieber, P.; Karsh, L.; Damião, R.; et al. Denosumab and bone-metastasis-free survival in men with castration-resistant prostate cancer: Results of a phase 3, randomised, placebo-controlled trial. Lancet Lond. Engl. 2012, 379, 39-46. [CrossRef]

133. Kantoff, P.W.; Higano, C.S.; Shore, N.D.; Berger, E.R.; Small, E.J.; Penson, D.F.; Redfern, C.H.; Ferrari, A.C.; Dreicer, R.; Sims, R.B.; et al. Sipuleucel-T immunotherapy for castration-resistant prostate cancer. N. Engl. J. Med. 2010, 363, 411-422. [CrossRef] [PubMed]

134. Antonarakis, E.S.; Lu, C.; Wang, H.; Luber, B.; Nakazawa, M.; Roeser, J.C.; Chen, Y.; Mohammad, T.A.; Chen, Y.; Fedor, H.L.; et al. AR-V7 and Resistance to Enzalutamide and Abiraterone in Prostate Cancer. N. Engl. J. Med. 2014, 371, 1028-1038. [CrossRef] [PubMed] 
135. Raza, S.; Meyer, M.; Goodyear, C.; Hammer, K.D.P.; Guo, B.; Ghribi, O. The cholesterol metabolite 27-hydroxycholesterol stimulates cell proliferation via ER $\beta$ in prostate cancer cells. Cancer Cell Int. 2017, 17, 52. [CrossRef] [PubMed]

136. Pencheva, N.; Buss, C.G.; Posada, J.; Merghoub, T.; Tavazoie, S.F. Broad-Spectrum Therapeutic Suppression of Metastatic Melanoma through Nuclear Hormone Receptor Activation. Cell 2014, 156, 986-1001. [CrossRef] [PubMed]

137. Segala, G.; David, M.; de Medina, P.; Poirot, M.C.; Serhan, N.; Vergez, F.; Mougel, A.; Saland, E.; Carayon, K.; Leignadier, J.; et al. Dendrogenin A drives LXR to trigger lethal autophagy in cancers. Nat. Commun. 2017, 8, 1903. [CrossRef] [PubMed]

138. Zhong, S.; Zhang, X.; Chen, L.; Ma, T.; Tang, J.; Zhao, J. Statin use and mortality in cancer patients: Systematic review and meta-analysis of observational studies. Cancer Treat. Rev. 2015, 41, 554-567. [CrossRef] [PubMed]

139. Platz, E.A.; Leitzmann, M.F.; Visvanathan, K.; Rimm, E.B.; Stampfer, M.J.; Willett, W.C.; Giovannucci, E. Statin drugs and risk of advanced prostate cancer. J. Natl. Cancer Inst. 2006, 98, 1819-1825. [CrossRef] [PubMed]

140. Loeb, S.; Kan, D.; Helfand, B.T.; Nadler, R.B.; Catalona, W.J. Is statin use associated with prostate cancer aggressiveness? BJU Int. 2010, 105, 1222-1225. [CrossRef] [PubMed]

141. Harshman, L.C.; Wang, X.; Nakabayashi, M.; Xie, W.; Valenca, L.; Werner, L.; Yu, Y.; Kantoff, A.M.; Sweeney, C.J.; Mucci, L.A.; et al. Statin Use at the Time of Initiation of Androgen Deprivation Therapy and Time to Progression in Patients With Hormone-Sensitive Prostate Cancer. JAMA Oncol. 2015, 1, 495-504. [CrossRef] [PubMed]

142. Harshman, L.C.; Werner, L.; Tripathi, A.; Wang, X.; Maughan, B.L.; Antonarakis, E.S.; Nakabayashi, M.; McKay, R.; Pomerantz, M.; Mucci, L.A.; et al. The impact of statin use on the efficacy of abiraterone acetate in patients with castration-resistant prostate cancer. Prostate 2017, 77, 1303-1311. [CrossRef] [PubMed]

143. Viennois, E.; Pommier, A.J.C.; Mouzat, K.; Oumeddour, A.; El Hajjaji, F.-Z.; Dufour, J.; Caira, F.; Volle, D.H.; Baron, S.; Lobaccaro, J.-M.A. Targeting liver X receptors in human health: Deadlock or promising trail? Expert. Opin. Ther. Targets 2011, 15, 219-232. [CrossRef] [PubMed]

144. Yasuda, T.; Grillot, D.; Billheimer, J.T.; Briand, F.; Delerive, P.; Huet, S.; Rader, D.J. Tissue-specific liver X receptor activation promotes macrophage RCT in vivo. Arterioscler. Thromb. Vasc. Biol. 2010, 30, 781-786. [CrossRef] [PubMed]

145. Stachel, S.J.; Zerbinatti, C.; Rudd, M.T.; Cosden, M.; Suon, S.; Nanda, K.K.; Wessner, K.; DiMuzio, J.; Maxwell, J.; Wu, Z.; et al. Identification and in Vivo Evaluation of Liver X Receptor $\beta$-Selective Agonists for the Potential Treatment of Alzheimer's Disease. J. Med. Chem. 2016, 59, 3489-3498. [CrossRef] [PubMed]

146. Kirchgessner, T.G.; Sleph, P.; Ostrowski, J.; Lupisella, J.; Ryan, C.S.; Liu, X.; Fernando, G.; Grimm, D.; Shipkova, P.; Zhang, R.; et al. Beneficial and Adverse Effects of an LXR Agonist on Human Lipid and Lipoprotein Metabolism and Circulating Neutrophils. Cell Metab. 2016, 24, 223-233. [CrossRef] [PubMed] 